\title{
PLACEMENT OF A PERSON IN A MEDICAL INSTITUTION IN ORDER TO CONDUCT A PSYCHIATRIC EXAMINATION: INTERNATIONAL STANDARDS AND NATIONAL REALITIES
}

DOI: 10.36740/WLek202009224

\author{
Olga I. Tyshchenko ${ }^{1}$, Ivan A. Titko ${ }^{2}$ \\ 'YAROSLAV MUDRYI NATIONAL LAW UNIVERSITY, KHARKIV, UKRAINE \\ 2POLTAVA LAW INSTITUTE OF YAROSLAV MUDRYI NATIONAL LAW UNIVERSITY, POLTAVA, UKRAINE
}

\begin{abstract}
The aim: The aim of this work is to identify the compliance level of modern practice of placement of a person in a medical institution in order to conduct the FPE to international standards and legal positions of the ECHR in terms of ensuring the right to liberty and security of person; formulation of scientifically substantiated proposals on the synchronization directions of national practices with the specified international standards.

Materials and methods: During the preparation of the article the following was processed: scientific research on ensuring the rights of persons suffering from mental disorders in criminal proceedings; provisions of international agreements on the provision of psychiatric care; legal positions of the ECHR on the observance of persons' rights suffering from mental disorders (15 judgments on this topic); criminal procedural legislation of individual states; results of generalization of national law enforcement practice; the results of a survey conducted by the authors of 18 psychiatrists who practice in the field of forensic psychiatric examinations (psychiatrists working in state psychiatric clinics in 0 desa, Poltava, Kharkiv were interviewed).

In the process of research a set of general scientific and special methods of cognition was used (comparative-legal method, system-structural method, generalization method, method of analysis and synthesis, method of sociological research, method of expert assessments, etc.).

Results: According to the research results: a) legal positions of the ECHR on the observance of the rights of persons suffering from mental disorders are identified and generalized; b) the compliance level of modern practice of placing a person in a medical institution in order to conduct the FPE with international standards and legal positions of the ECHR in terms of ensuring the right to liberty and security of person ( $\$ 1$ of Article 5 of the Convention); $c$ ) the degree of extrapolation of these positions to the activities of psychiatrists is analyzed; $d$ ) the optimal ways of solving the existing problems in the aspect of ensuring the rights of a person when placing them in a medical institution for an inpatient FPE are proposed.

Conclusions: The current national practice of placing a person in a medical institution for an inpatient FPE does not fully comply with the legal positions of the ECHR in terms of ensuring the right to liberty and security of person (in particular, there are deviations from the positions of the ECHR on: determining the documentary basis for the appointment of an inpatient FPE; interaction of police and medical workers in the field of psychiatry during the detention of a person with a mental disorder).
\end{abstract}

KEY WORDS: outpatient psychiatric examination, diagnosis of mental disorders, expert opinion, medical certificate, right to liberty, ECHR practice, forensic psychiatric examination

Wiad Lek. 2020;73(9 p. II):2020-2025

\section{INTRODUCTION}

According to the World Health Organization, mental disorders are one of the top public health challenges in the WHO European Region, affecting about $25 \%$ of the population every year [1]. At the same time, painful mental states are often the cause of deviant behavior, which is often expressed in the commission of socially dangerous acts by a person. In view of the above, the legislation of most states provides for the possibility of applying special medical response measures to such persons. However, the use of the latter is usually possible only after appropriate diagnostic measures. In turn, the possibilities of outpatient diagnosis of mental disorders are sometimes limited, and therefore there is a need for an inpatient FPE. In addition, this expertise, due to its specificity (significant restriction of personal liberty) may in some cases border on human rights violations (in particular, the prohibition of torture (Art. 3 of the Convention), the right to liberty and security of person (Art. 5 of the Convention)). Therefore, the conformity of national approaches to this issue to the formulated international standards (primarily in the ECHR judgments) is of particular importance.

\section{THE AIM}

The aim of this work is to identify the compliance level of modern practice of placement of a person in a medical institution in order to conduct the FPE to international standards and legal positions of the ECHR in terms of ensuring the right to liberty and security of person; formulation of scientifically substantiated proposals on the synchronization directions of national practices with the specified international standards. 


\section{MATERIALS AND METHODS}

During the preparation of the article the following was processed: scientific research on ensuring the rights of persons suffering from mental disorders in criminal proceedings; provisions of international agreements on the provision of psychiatric care; legal positions of the ECHR on the observance of persons' rights suffering from mental disorders (15 judgments on this topic); criminal procedural legislation of individual states (Belarus, Lithuania, Moldova, the Russian Federation, Estonia, Uzbekistan, Ukraine, Poland); results of generalization of national law enforcement practice (more than 30 judgments of courts of Ukraine for 2019-2020 were processed); the results of a survey conducted by the authors of 18 psychiatrists who practice in the field of forensic psychiatric examinations (psychiatrists working in state psychiatric clinics in Odesa, Poltava, Kharkiv were interviewed).

In the process of research a set of general scientific and special methods of cognition was used (comparative-legal method, system-structural method, generalization method, method of analysis and synthesis, method of sociological research, method of expert assessments, etc.).

\section{RESULTS}

Placement of a person in a medical institution in order to conduct the FPE in the context of international standards and legal positions of the ECHR on ensuring the right to liberty and security of person (\$1 (e) of Art. 5 of the Convention). International standardization of psychiatric care in general, and placement of a person in a medical institution for the conduct of the FPE in particular, is provided by international treaties and acts of a recommendatory nature, among which it is worth mentioning the Universal Declaration of Human Rights, 10 December 1948; European Convention on Human Rights, 04 November 1950; Declaration on the Rights of Mentally Retarded Persons, adopted by the UN General Assembly, 20 December 1971; Declaration on the Rights of Disabled Persons, adopted by the UN General Assembly, 9 December 1975; Recommendation (818) on the situation of the mentally ill, Council of Europe Parliamentary Assembly, 8 October 1977; Recommendation No. R (83) 2 of the Committee of Ministers to member states concerning the legal protection of persons suffering from mental disorder placed as involuntary patients, Council of Europe, 22 February 1983; The Principles for the Protection of Persons with Mental Illness and the Improvement of Mental Health Care, Resolution adopted by the UN General Assembly, 17 December 1991; Psychiatry and human rights, Council of Europe Parliamentary Assembly Recommendation 1235, 12 April 1994; Mental Health Declaration for Europe: Facing the Challenges, Building Solutions, adopted at the WHO European Ministerial Conference on Mental Health in Helsinki, Finland, 14 January 2005 etc.

Undoubtedly, the coercive conduct of the FPE is regulated at the level of domestic legislation of individual states (in particular, in the criminal procedural context it is worth mentioning Art. 509 of the Criminal Procedure
Code (CPC) of Ukraine, Art. 443 of the CPC of Belarus, Art. 569 of the CPC of Uzbekistan, Art. 435 of the CPC of the Russian Federation; Art. 74 of the CPC of Poland, etc.). Since the legal nature of this institution is common to these states, a comparative analysis of its regulations is of scientific interest in terms of possible regulatory borrowing, which will be discussed further.

Placement of a person in a medical institution for conducting the FPE is in fact a compulsory isolation measure, which restricts a person's right to freedom around the clock during the term of appointment of the FPE. However, in accordance with $\$ 1$ (e) of Art. 5 of the Convention, everyone has the right to liberty and security of person. No one shall be deprived of his liberty save in the following cases and in accordance with a procedure prescribed by law: the lawful detention of persons for the prevention of the spreading of infectious diseases, of persons of unsound mind, alcoholics or drug addicts or vagrants. In the context of the interpretation of Art. 5 of the Convention, researchers consider the meaning of the words "arrest" or "detention" as a loss of liberty [2, p. 292-303]. In particular, as follows from the content of $\$ 1$ (e) of Art. 5 of the Convention, it is a question of lawful detention of persons of unsound mind. Namely, it is about detention of a person who has actually been diagnosed with a certain type of mental disorder. In this context, it is of particular importance to clarify whether the placement of a person in a medical institution in order to conduct the FPE qualifies as imprisonment in accordance with $₫ 1$ of Art. 5 of the Convention. Thus, in the case law, the ECHR has repeatedly noted that $\$ 1$ of Art. 5 of the Convention requires that in any case of liberty deprivation to ensure the purpose of Art. 5 of the Convention, namely the protection of individuals against arbitrariness (See at: $\$ 35$ of the Case of Kornev and Karpenko v. Ukraine; $\$ 46$ of the Case of Aerts v. Belgium [3,4]). In this case, the Court emphasizes that deprivation of liberty is not limited to the classic cases of deprivation as a result of arrest or sentencing, but may take numerous other forms ( $\$ 95$ of the Case of Guzzardi v. Italy). Thus, in order to determine whether deprivation of liberty has taken place, the starting point can be a specific situation in which a number of factors should be taken into account, such as: type, duration, consequences and method of application of this measure (See at: $₫ 92$ of the Case of Guzzardi v. Italy; $₫ 67$ of the Case of Nielsen v. Denmark; $₫ 42$ of the Case of H.M. v. Switzerland) $[5,6,7])$. Thus, in the case law of the ECHR it is emphasized that the concept of deprivation of liberty combines both an objective element (keeping a person in a confined space for a significant period of time) and a subjective element (lack of reliable consent of a person to such detention) (See at: $\$ 74$ of the Case of Storck v. Germany; $\$ 117$ of the Case of Stanev v. Bulgaria; $\$ 67$ of the Case of Akopyan v. Ukraine) [8, 9, 10]. Interpreting the above legal positions of the ECHR in the context of placement of a person in a medical institution in order to conduct the FPE, we should note that in terms of deprivation of liberty concept, this measure combines an objective element (inpatient detention of a person in a medical institution for 
a period of two months) and a subjective element (lack of reliable consent of the person to such inpatient detention in order to conduct the FPE). That is, by its legal nature, this measure is related to the restriction of a person's right to liberty (Article $5 \$ 1$ (e) of the Convention), as in fact they are forced to remain territorially within the relevant medical institution for a long time (See also $₫ 105$ of the Case of Anatoliy Rudenko v. Ukraine [11]). However, in the absence of a subjective element (i.e., the person voluntarily agrees to be placed in the inpatient medical facility for the FPE), is it legitimate to consider this measure within the concept meaning of "deprivation of liberty"? In particular, the answer to this question is contained in the legal position expressed by the ECHR in $\$ 64-65$ of the Case of De Wilde, Ooms and Versyp ("Vagrancy") v. Belgium (Merits), in which the applicants voluntarily appeared before the police to be taken into custody. However, the Court has ruled that the right to liberty and security of person is too important in a democratic society for a person to be deprived of the guarantees of protection enshrined in the Convention solely on the basis of voluntary attendance at the police station [12]. The Court expressed a similar legal position in $\$ 119$ of the Case of Stanev v. Bulgaria [13]. Accordingly, the above legal position of the ECHR can be legally applied in the case of voluntary consent of a person to placement in a medical institution for the purpose of conducting the FPE. In this case, it is also a question of deprivation of the right to liberty and security of person, the guarantees of protection of which (provided for in Art. 5 of the Convention) do not lose their effect.

The conclusion of the outpatient examination on the mental state of the person as a documentary basis for placing a person in a medical institution in order to conduct the FPE. In its case law, the ECHR has repeatedly pointed out that the deprivation of liberty of a person of unsound mind cannot be regarded as meeting the requirements of Art. $5 \S$ 1 (e), if the decision on such deprivation was made without the opinion of a medical expert (See at: $\$ 59$ of the Case of Ruiz Rivera v. Switzerland; $\$ 31$ of the Case of S.R. v. the Netherlands $[14,15])$. However, the application of these legal positions during the appointment of an inpatient FPE can not be considered relevant, because the decisions of the ECHR refers to the established fact that a person has a mental disorder, and at the time of appointment of an inpatient FPE, the person's diagnosis is unknown (in fact, such an examination is appointed in order to obtain it). However, in the decision of the Case of Varbanov v. Bulgaria, the ECHR emphasized that no deprivation of liberty of a person considered to be of unsound mind may be deemed in conformity with Article $5 \$ 1$ (e) of the Convention if it has been ordered without seeking the opinion of a medical expert. This rule applies even if the purpose of the applicant's detention is to obtain a medical opinion ( $\$ 48$ of the Case of Varbanov v. Bulgaria) [16]. A similar conclusion was reached by the ECHR in the Case of Kepenerov v. Bulgaria, in which the applicant failed to comply with the prosecutor's order to undergo a psychiatric examination, was detained on that basis and forcibly taken to a medical facility, where he was detained for 30 days. The court ruled that the domestic law governing the isolation of persons on mental health grounds did not authorize the prosecutor to subject the applicant to involuntary solitary confinement in a psychiatric clinic for the psychiatric examination. In addition, the current Bulgarian legislation did not oblige the authorities to obtain a medical opinion for isolation. The court noted that the applicant's detention had been unlawful within the meaning of Art. $5 \$ 1$ of the Convention, as... did not require the seeking of an expert medical opinion to be placed in a specialized institution ( $\$ 35$ of the Case of Kepenerov v. Bulgaria) [17].

That is, a literal interpretation of the above legal positions of the ECHR allows to state that the purpose of inpatient detention in an expert institution is to obtain an expert opinion on the mental state of the person. In turn, the documentary basis for sending a person to the medical institution for an inpatient FPE is the initial conclusion of the outpatient examination, in which, if it is impossible to answer questions during the outpatient FPE, the expert must justify the need for the FPE inpatient form.

Survey results: $55.6 \%$ of psychiatric experts we surveyed expressed the belief that an inpatient FPE can be conducted only on the basis of a preliminary outpatient examination of the person's mental state, in which the expert must justify the need to conduct it in a stationary form (in case of impossibility to provide a categorical conclusion on the diagnosis of the person).

Medical certificate of mental disorder of the person as an alternative to a preliminary expert opinion. In this context, it is worth noting the differences in national practices. For example, the CPC of Ukraine does not clearly provide for the existence of such a certificate as a basis for sending a person to an inpatient FPE. While Part 1 of Art. 569 of the CPC of Uzbekistan determines the grounds for the appointment of an inpatient FPE as the conclusions of the outpatient examination and other medical documents. At the same time, Ukrainian jurisprudence shows that on the basis of this medical document, judges quite often satisfy the request of the investigator, the prosecutor to send a person to an inpatient FPE. However, based on the above legal positions of the ECHR, a medical certificate of a person with a mental disorder can not be a basis for the appointment of an inpatient FPE. In this case, there is a false identification of the conclusion of the outpatient psychiatric examination and a medical certificate confirming the presence of a person's mental disorder.

Survey results: $66.7 \%$ of the psychiatric experts we surveyed indicated that a medical certificate stating that a person has a mental disorder (instead of an outpatient examination report) could not be a basis for placing a person in a medical institution for the FPE.

Term of an inpatient FPE and its extension. The urgency of this issue is obvious primarily to states whose legislation sets a time limit on the duration of the FPE, but does not provide for the possibility of increasing such duration if necessary. An example of this is Ukraine, where the law provides that in case of need for long-term observation 
and examination of a person may, an inpatient psychiatric examination may be performed, for which such a person is sent to the relevant medical institution for a period not exceeding two months (Part 2 of Art. 509 of the CPC of Ukraine). However, the question of the maximum duration of a person's stay in a medical institution during an inpatient FPE and the procedure for its extension remains unresolved (in contrast, for example, to such states as Estonia, Lithuania, Moldova, Uzbekistan). The problem is that with this approach, if the two-month period was exhausted during the initial examination, the possibility of conducting a repeat or additional inpatient FPE is questionable. However, in the presence of a probable conclusion of the primary FPE on the person's mental state, the exhaustion of the two-month period, combined with the absence of a procedural mechanism for its extension, would lead to a vicious circle of legal impasse. Namely, it would be procedurally incapable to legally resolve the issue of sentencing in relation to a person whose mental state is unknown.

Survey results: To the question "Were there any situations in your practice in which it was impossible to determine the mental state of a person by conducting an inpatient FPE?" only one of the 18 psychiatrists surveyed answered in the affirmative. This testifies to the rarity of such situations, but at the same time indicates their existence.

As it is rightly emphasized by Tijs Kooijmans, Gerben Meynen, "If behavioral experts cannot reach the conclusion - based on their own research and/or based on previous behavioral examinations of the defendant - that the defendant suffers from a mental disease or mental defect, the judge should refrain from an assessment that the defendant nevertheless suffers from a psychiatric illness. The consequence of this line of reasoning is that the judge would indeed be limited with regard to the possibilities of disposal of the criminal case" [18, p. 6].

Therefore, the need to regulate the procedure for extending the term of an inpatient FPE is more than obvious. In the comparative aspect, we should note that the procedural mechanisms for extending such a period are provided, for example, by the criminal procedural legislation of Uzbekistan (Art. 265 of the CPC); Moldova (Art. 152 of the CPC); Lithuania (Art. 141 of the CPC); Estonia (Art. 102 of the $\mathrm{CPC}$ ) and others ${ }^{1}$.

Survey results: $16.7 \%$ of respondents admitted that there may be situations in which a two-month period of an inpatient FPE will not be enough to provide a complete and objective conclusion, and therefore there will be a need to extend the period of a person's stay in a psychiatric hospital. The respondents indicated 3 months as the maximum term for this.

Features of police detention of a person suffering from a mental disorder. Of particular importance in criminal proceedings is the question of the effective interaction of the police with medical workers in the field of psychiatry during the detention of a person suffering from a mental disorder. We should consider it in the analysis context of the Case of Shchiborshch and Kuzmina v. Russia [19], the main circumstances of which are as follows. Thus, 37-yearold K. Shchiborshch was an economist and author of more than 100 publications. He suffered from mental disorders that required inpatient treatment. During the aggravation of K. Shchiborshch's health (he raved and did not allow anyone to enter his apartment), his father asked the police to help hospitalize his son in a psychiatric institution. During unsuccessful attempts by the police to take him to a psychiatric hospital, K. Shchiborshch resisted, injuring several police officers with a kitchen knife, as a result of which police officers called a special unit of operational purpose to the scene for help. During the storming of the apartment K. Shchiborshch received serious injuries, with which he was taken in a coma to the hospital, where he died a few hours later. Criminal proceedings were instituted against the police officers, which were subsequently closed because it was recognized that the use of force by the police officers was in accordance with the law. However, in this case the ECHR found a violation of Art. 2 of the Convention (right to life) in part: 1) lack of planning and control of the operation of involuntary hospitalization of K. Shchiborshch; 2) evasion of an effective investigation into the event that led to the death of K. Shchiborshch. Thus, the ECHR noted that the investigating authorities did not investigate why the police acted independently, without the participation of psychiatrists, in violation of the Law on Psychiatric Care. In addition, the ECHR emphasized that the investigating authorities had considered the situation if an armed offender had acted in it, without taking into account the mental state of K. Shchiborshch ( $\$ 258$ of the Case of Shchiborshch and Kuzmina v. Russia).

The above case clearly demonstrates the special importance of adhering to the principle of cooperation between police officers and medical workers in the field of psychiatry during the detention of a person suffering from mental disorders. This principle is aimed at the joint effective implementation of these entities of two interrelated tasks from the standpoint of ensuring the rights of such a person. Thus, during the detention of persons suffering from a mental disorder, the special importance of the participation of psychiatrists is to establish psychological contact with them, which can prevent or minimize the risks of potential danger to themselves and others around them. That is, psychiatrists should provide qualified communication with persons suffering from a mental disorder in order to convince them of the need to comply with the lawful requirements of police officers. In turn, police officers must provide a security regime for the professional interaction of medical workers with a person suffering from a mental disorder, and detain the person.

Survey results: To our question to psychiatric experts "Can the participation of a psychiatrist in the police detention of a person suffering from a mental disorder help

${ }^{1}$ In our opinion, the extension of the term of an inpatient FPE in Ukraine may take place in accordance with Articles 197 and 199 of the CPC of Ukraine for the extension of detention (as, for example, in Lithuania). 
to establish psychological contact with them and prevent or minimize the risks of potential danger to this person for themselves and others?", the answers were distributed as follows: $27.8 \%$ of respondents gave an affirmative answer; $11.1 \%$ of respondents indicated the likelihood that such participation could be effective; $61.1 \%$ gave a negative answer. Interpreting the results, it is possible to assume that the rejection of the idea by the vast majority of psychiatrists can be explained by subconscious or conscious projection on their own professional activities of the inconvenience that may entail the implementation of this idea (in particular, the need to participate in conflict situations outside a specialized psychiatric institution).

\section{DISCUSSION}

The involuntary placement of a person in a psychiatric institution has already been the subject of scientific consideration in a medical aspect (see at: Saya A., Brugnoli C., Piazzi G., Liberato D., Di Ciaccia G., Niolu C., \& Siracusano A. [20]), and in law one (see at: Tijs Kooijmans and Gerben Meynen [18] and Christopher Slobogin [21]), in particular in criminal procedure (see at: Ruchina O. [22], Tsokolova O. [23]). The special vulnerability of persons suffering from mental disorders is due to the increased scientific interest in ensuring their rights in criminal proceedings. This vector of scientific research has been adopted by such authors as Peter Verbeke, Gert Vermeulen, Tom Vander Beken, Michaël Meysman [24]; Stephen J. Morse [25] and others. The issue of ensuring the rights of persons with mental disorders during criminal proceedings was also considered by the authors of this article together with Olena A. Leiba [26]. Since the use of coercion in the provision of medical care always raises the question of the proportionality of such coercion with the desired result, in this regard, we should mention the work of A. Nilsson [27]. The issue of action in the law enforcement and medical practice of Ukraine of international standards for the application of coercive measures of a medical nature was raised by Andrii V. Lapkin, Daryna P. Yevtieieva, Vladyslav V. Karelin [28]. At the same time, the review of works allows to state that at present a number of questions connected with definition of the bases and procedural order of placement of the person in a medical institution in order to conduct the FPE remains debatable. At the present stage, it is necessary to understand the compliance of national law enforcement practices with the legal positions of the ECHR and international standards in general in the context of ensuring the rights of persons for whom an inpatient FPE is appointed.

\section{CONCLUSIONS}

1. Interpreting the legal position of the ECHR in the context of placing a person in a medical institution in order to conduct the FPE, it should be noted that this measure combines both components of restriction of the right to liberty: objective element (inpatient detention) and subjective element (lack of reliable consent of the person to such stationary maintenance in order to conduct the FPE). Therefore, by its legal nature, the placement of a person in a medical institution in order to conduct the FPE is certainly a restriction of a person's right to liberty in the context of Art. 5 of the Convention.

2. The analysis of the case law of the ECHR allows us to state that the documentary basis for placing a person in a medical institution for the FPE is an expert opinion. If it is impossible to answer the questions posed during the outpatient FPE, the expert must justify the need for it in an inpatient form. At the same time, identifying the conclusion of an outpatient psychiatric examination and a medical certificate confirming the presence of a person's mental disorder is an erroneous approach, as a medical certificate cannot be a basis for the appointment of an inpatient FPE.

3. At the level of national legislation, the mechanism for extending the period of an inpatient FPE should be regulated (in the legal field of Ukraine, it may be similar to the procedure for extending the period of detention, as, for example, in Lithuania). The deadline should not exceed 3 months.

4. During the detention of a person suffering from a mental disorder, the principle of cooperation between the police and medical staff in the field of psychiatry formulated by the ECHR is of particular importance. Psychiatrists should provide qualified communication with a person suffering from a mental disorder in order to convince them of the need to comply with the lawful requirements of police officers. In turn, police officers must provide a security regime for the professional interaction of medical workers with a person suffering from a mental disorder, and detain the person.

\section{REFERENCES}

1. The European Mental Health Action Plan 2013-2020. WHO Regional Office for Europe.

2. Harris D.J., O'Boyle M., Bates E.P. et al. Harris, O'Boyle \&Warbrick: Law of the European Convention on Human Rights. 2018; 1056.

3. Case of Kornev and Karpenko v. Ukraine (Application no. 17444/04) 21 October 2010.

4. Case of Aerts v. Belgium (Application no. 61/1997/845/1051) 30 July 1998.

5. Case of Guzzardi v. Italy (Application no. 7367/76) 6 November 1980.

6. Case of Nielsen v. Denmark (Application no. 10929/84) 28 November 1988.

7. Case of H.M. v. Switzerland (Application no. 39187/98) 26 February 2002.

8. Case of Storck v. Germany (Application no. 61603/00) 16 June 2005.

9. Case of Stanev v. Bulgaria (Application no. 36760/06) 17 January 2012.

10. Case of Akopyan v. Ukraine (Application no. 12317/06) 5 June 2014.

11. Case of Anatoliy Rudenko v. Ukraine (Application no. 50264/08) 17 April 2014.

12. Cases of De Wilde, Ooms and Versyp («Vagrancy») v. Belgium (Merits) (Application no. 2832/66;2835/66; 2899/66) 18 June 1971.

13. Case of Stanev v. Bulgaria (Application no. 36760/06) 17 January 2012.

14. Case of Ruiz Rivera v. Switzerland (Application no. 8300/06) 18 February 2014, 18 May 2014.

15. CaseS. R. v. the Netherlands (Application no. 13837/07) 18September 2012. 16. Case of Varbanov v. Bulgaria (Application no. 31365/96) 50 ctober 2000.

17. Case of Kepenerov v Bulgaria (Application no. 39269/98) 31 July 2003. 
18. Kooijmans T., Meynen G. Who Establishes the Presence of a Mental Disorder in Defendants? Medicolegal Considerations on a European Court of Human Rights Case. Frontiers in Psychiatry. October 2017;8(199):1-6.

19. Case of Shchiborshch and Kuzmina v. Russia (Application no. 5269/08) 16 January 2014.

20. Saya A., Brugnoli C., Piazzi G. et al. (2019). Criteria, Procedures, and Future Prospects of Involuntary Treatment in Psychiatry Around the World: A Narrative Review. Frontiers in psychiatry. 2019;10:271. https://doi. org/10.3389/fpsyt.2019.00271

21. Slobogin C. Eliminating mental disability as a legal criterion in deprivation of liberty cases: The impact of the Convention on the Rights of Persons with Disabilities on the insanity defense, civil commitment, and competency law. International Journal of Law and Psychiatry. 2016;40:36-42.

22. Ruchina A. 0 pravovoy prirode primeneniya mer prinuzhdeniya $\mathrm{k}$ litsu, $v$ otnoshenii kotorogo vedyotsya proizvodstvo o primenenii prinuditelnyih mer meditsinskogo haraktera [0n the legal nature of the application of coercive measures against a person in respect of which proceedings are being conducted on the application of coercive medical measures]. Vestnik Vostochno-Sibirskogo instituta MVD Rossii. 2019;1:84-90. (In Russian).

23. Tsokolova 0. Problemyi pravovogo regulirovaniya pomescheniya podozrevaemogo, obvinyaemogo v meditsinskuyu organizatsiyu, okazyivayuschuyu psihiatricheskuyu pomosch v statsionarnyih usloviyah [Problems of legal regulation of placing the suspect, the accused in a medical organization providing psychiatric care in a hospital]. Probely v rossiyskom zakonodatelstve. 2017:1:24-27. (in Russian).

24. Verbeke P., Vermeulen G., Beken T. et al. Protecting the fair trial rights of mentally disordered defendants in criminal proceedings: exploring the need for further EU action. International journal of law and psychiatry. 2015;41:67-75.

25. Morse S.J. Mental disorder and Criminal law. The journal of Criminal law \& criminology. 2011;101(3):885-968.

26. Tyshchenko 0.I., Leiba 0.A., Titko I.A. European standards of respect for human rights in the application of coercive medical measures in criminal proceedings. Wiad Lek. 2019;72(12)2:2445-2450.
27. Nilsson A. Minding Equality: Compulsory Mental Health Interventions and the CRPD. Doctoral thesis. Lund. 2017;230.

28. Lapkin A.V., Yevtieieva D.P., Karelin V.V. European standards of respect for human rights in the application of compulsory medical measures in criminal proceedings. Wiad Lek. 2019;72(12)2:2479-2484.

ORCID and contributionship:

Olga I. Tyshchenko: 0000-0003-1551-1367 A, B, C

Ivan A. Titko: 0000-0003-4126-6967 ${ }^{\text {B, D, E, F }}$

\section{Conflict of interest:}

The Authors declare no conflict of interest.

\author{
CORRESPONDING AUTHOR \\ Ivan A. Titko \\ Poltava Law Institute of Yaroslav Mudryi National Law University \\ 5 Pervomaisky Av., 36000 Poltava, Ukraine \\ tel: +380975150748 \\ e-mail: titko.iv@gmail.com
}

Received: 22.04 .2020

Accepted: 05.08 .2020 